\title{
Corruption, Innovation and Firm Growth: Firm-level Evidence from Egypt and Tunisia
}

Citation for published version (APA):

Goedhuys - Degelin, M., Mohnen, P., \& Taha, T. (2016). Corruption, Innovation and Firm Growth: Firmlevel Evidence from Egypt and Tunisia. Eurasian Business Review, 6(3), 299-322. https://doi.org/10.1007/s40821-016-0062-4

Document status and date:

Published: 01/12/2016

DOI:

10.1007/s40821-016-0062-4

Document Version:

Accepted author manuscript (Peer reviewed / editorial board version)

\section{Please check the document version of this publication:}

- A submitted manuscript is the version of the article upon submission and before peer-review. There can be important differences between the submitted version and the official published version of record.

People interested in the research are advised to contact the author for the final version of the publication, or visit the DOI to the publisher's website.

- The final author version and the galley proof are versions of the publication after peer review.

- The final published version features the final layout of the paper including the volume, issue and page numbers.

Link to publication

\footnotetext{
General rights rights.

- You may freely distribute the URL identifying the publication in the public portal. please follow below link for the End User Agreement:

www.umlib.nl/taverne-license

Take down policy

If you believe that this document breaches copyright please contact us at:

repository@maastrichtuniversity.nl

providing details and we will investigate your claim.
}

Copyright and moral rights for the publications made accessible in the public portal are retained by the authors and/or other copyright owners and it is a condition of accessing publications that users recognise and abide by the legal requirements associated with these

- Users may download and print one copy of any publication from the public portal for the purpose of private study or research.

- You may not further distribute the material or use it for any profit-making activity or commercial gain

If the publication is distributed under the terms of Article $25 \mathrm{fa}$ of the Dutch Copyright Act, indicated by the "Taverne" license above, 
Corruption, Innovation and Firm Growth: Firm-level Evidence from Egypt and Tunisia

\author{
Micheline Goedhuys ${ }^{\text {a }}$ \\ Pierre Mohnen ${ }^{\mathrm{a}, \mathrm{b}}$ \\ Tamer Taha ${ }^{\mathrm{a}}$
}

\begin{abstract}
Using recently collected firm-level data from Egypt and Tunisia, this paper explores the effect of institutional obstacles and corruption on the innovative behavior of firms and their effect on firms' employment growth. We estimate the micro-level interactions between corruption and institutional obstacles and test the hypothesis that corruption 'greases the wheels' of firm performance when bureaucratic procedures are more severe and hampering innovation. Accounting for endogeneity and simultaneity, the paper uses a conditional recursive mixed-process model (CMP). The results show that corruption has a direct negative effect on the likelihood that a firm is an innovator, but a positive effect when interacted with institutional obstacles. This provides support for the hypothesis that corruption serves as a mechanism to bypass the bureaucratic obstacles related to obtaining the necessary business permits and licenses for product innovation. These effects also resonate into firm growth, through their effect on product innovation.
\end{abstract}

JEL: 012, 031, L25, D73

Keywords: Innovation, corruption, employment growth, Egypt, Tunisia

\footnotetext{
a UNU-MERIT Boschstraat 24, 6211 AX Maastricht, the Netherlands

${ }^{\mathrm{b}}$ Maastricht University, SBE, Tongersestraat 35, Maastricht, the Netherlands

Corresponding author: Micheline Goedhuys, Goedhuys@merit.unu.edu tel: +31 4338844 54; fax: +31433884499
} 


\section{Introduction}

Innovation and technical progress are undoubtedly recognized as key factors for maintaining and raising the competitiveness of firms and the main engine for economic growth of national economies in the long-term (Grossman and Helpman, 1993; Nelson and Winter, 1982; Romer, 1990). Differences in innovation and growth performance are often explained by differences in institutions and quality of governance, in particular corruption (Mo, 2001; Mauro, 1995). Following the traditional institutional economics theory, corruption raises transaction costs and therefore it hinders investment in R\&D and other productive activities. Additionally, corruption increases the distrust and uncertainty in governmental institutions and the business climate in general - both necessary for a conducive environment for innovation (Anokhin and Schulze, 2009). This negative "sanding the wheels" hypothesis of corruption on firm innovation contrasts with the view of some scholars arguing that corruption may accelerate innovation, especially in economies with relatively poor quality of governance, by speeding up procedures to obtain the needed bureaucratic permits and "getting things done", the so-called "greasing the wheels" hypothesis.

Macroeconomic studies examining this relationship empirically have raised various methodological issues (Fisman and Svensson, 2007). Cross-country studies often provide an aggregate measure of corruption and innovation, based on the overall perception of experts in a given economy, creating possibly a perception bias. Second, macro-economic data do not reveal the heterogeneity within a country. Third, macroeconomic studies do not explain the detailed mechanisms at the firm-level and consequently may be misleading for policy makers. Indeed, it is possible to find a negative effect of corruption at the aggregate level, but not at the micro level. This would occur if bribery payments are a means for firms to improve their position relative to those that do not pay bribes, a likely scenario that would explain the pervasiveness and persistence of the phenomenon.

Empirically, at the micro level, only a few studies have addressed the effect of corruption on firm performance. This paper tries to fill the gap and empirically investigates to what extent institutional barriers and corruption affect the performance of firms in developing economies. This study addresses the question of whether corruption "greases" the innovation and growth of firms by accelerating bureaucratic procedures, or rather "sands" it by deviating investments away from productive activities. 
The paper uses survey data from Egypt and Tunisia, two countries that are representative for the larger Middle East and North Africa ${ }^{1}$ (MENA) region. Corruption has been persistently high in the MENA. In 2015, 83 percent of the MENA countries have scored below 55 in the Corruption Perception Index ${ }^{2}$, compared to 23 percent in EU and Western Europe and 74 percent worldwide (Transparency International, 2015). According to the World Bank Enterprise Survey (WBES), the region has the highest levels of corruption with 55.1 percent of firms identifying corruption as a major concern ${ }^{3}$.

The region is also lagging behind when it comes to innovation, compared to other regions at the same level of development. According to the Global Innovation Index 2015 (Cornell University, INSEAD and WIPO, 2015), the ranking of the MENA countries is as low as $141^{\text {st }}$ for Sudan, $137^{\text {th }}$ for Yemen and $100^{\text {th }}$ for Egypt and $76^{\text {th }}$ for Tunisia. ${ }^{4}$ Using macro-data from various countries, Guetat (2006) has shown that both corruption and poor bureaucratic quality depress growth, but are especially detrimental for countries from the MENA region. A study on the micro-level on corruption, innovation and growth is needed to validate and deepen this finding and is highly relevant to this part of the world that struggles to implement economic reforms and build institutions stimulating innovative knowledge-based entrepreneurship in the aftermath of the Arab Spring (World Bank, 2013).

The paper contributes to the literature in various ways. First, the paper explicitly tests whether the effect of corruption on innovation depends on the severity of bureaucratic obstacles and red tape. In doing so, it teases out the mediating effects of corruption and institutional obstacles affecting economic performance. Second, the paper provides a better understanding of the factors explaining the innovation performance in Egypt and Tunisia. The MENA region suffers from a scarcity of firm-level and harmonized cross-country data (Atiyas, 2011), especially on innovation activities, making the micro-economics of innovation an understudied topic in the MENA. Therefore, this paper provides new insights

\footnotetext{
1 This study uses the term "MENA region" to describe the following countries: Djibouti, Egypt, Palestine, Israel, Jordan, Morocco, Lebanon, Tunisia, and Yemen. The choice of countries is dictated by data availability and in accordance to the World Bank's regional grouping.

${ }^{2}$ A country's score indicates the perceived level of public sector corruption on a scale of $0-100$, where 0 means that a country is perceived as highly corrupt and a 100 means that a country is perceived as very clean.

3 Out of these firms, 25.2 percent have experienced at least one bribery payment request to accelerate the bureaucratic processes, compared to respectively 34 and 17 percent worldwide Enterprise Surveys (http://www.enterprisesurveys.org), The World Bank.

${ }^{4}$ From a micro perspective, firms from MENA have the least performance in innovative activities. The region has an average capacity utilization of 62.7 percent, a net decrease of labour productivity of 10.5 percent and only 5.4 percent of firms are using a technology licensed from a foreign company, compared respectively to $72.2 \%, 2.9 \%$ and $14.8 \%$ for the worldwide average. Source: Enterprise Surveys (ibid).
} 
on both the determinants and obstacles to innovation. Most innovation studies describe the factors determining the firms' innovativeness, such as R\&D, yet few efforts have focused on the barriers hindering innovation. The paper tries to contribute to the literature that adopts the barriers approach (e.g. Galia and Legros, 2004; Mohnen and Rosa, 2001; Wziatek-kubiak and Peczkowski, 2010). Nonetheless, in this strand of the literature most of the focus is placed on the hampering effect of financial burden and other firms' characteristics, such as firm's size, age, type of ownership, on innovation, rarely discussing corruption and institutional quality. Third, the paper extends the model in order to test for the further effects of corruption, bureaucratic quality and innovation on the (employment) growth of firms. Finally, the paper uses a novel approach to control for potential endogeneity between corruption and innovation using a conditional recursive mixed-process (CMP) model.

The paper is structured as follows: Section two discusses the literature on the various channels by which corruption affects the economic performance of firms and provides evidence from previous empirical papers. Section three presents the dataset used in our study and the estimation techniques using the CMP model. Section four presents the results of the analysis, including some robustness checks. Section five concludes and discusses some implications for policy.

2. Conceptual framework and literature review

Innovation is the process by which firms introduce new products, production processes, marketing and organizational methods thereby increasing their competitive advantage, productivity, efficiency and hence growth potential. ${ }^{5}$ However, firms do not innovate in isolation and successful innovations result from a variety of interactive relationships within the national innovation system (Freeman, 1987; Lundvall, Joseph and Chaminade, 2009). Therefore, the quality of the institutions in the innovation systems affects profoundly the innovation outcomes of economic agents, as it defines how skills, artefacts and knowledge are created, stored, and transferred (Edquist and Jöhnson, 1997; North, 1990; OECD, 1999).

\footnotetext{
${ }^{5}$ An innovation is the introduction of products, production processes, marketing and organizational methods that are new to the firm, irrespective of whether they are new to the firm's competitors, its market or the world. Conceptually this definition follows the OECD (2005) Oslo Manual and is a measure of diffusion of technology and knowledge.
} 
This aligns with the institutional economics literature, where institutions are meant to reduce the uncertainty in human interactions based on rules, norms and values (North, 1990).

Corruption is commonly defined as the abuse of public power or authority for private benefit (Rodriguez, Siegel, Hillman and Eden, 2006). Corruption may take the forms of bribery, extortion, embezzlement, and fraud (Lambsdorff, 2007). Other economists, such as Andvig and Fjeldstad (2000), derive the concept from the principal-agent theory. They define it as the exchange of favors between two actors, an agent and a client. In this paper we define corruption as any transaction between profit driven firms and government officials or representatives. Firms pay bribes or informal payments to government officials in exchange of a favor that benefits the business performance, such as better or faster government services or the securing of contracts.

Two main strands can be found in the literature with competing and opposing hypotheses addressing the effect of corruption on economic performance. The first set of hypotheses suggests that corruption can be considered a major impediment for economic performance. The opposing hypotheses suggest that corruption may help bypassing other existing obstacles faced by the firm, mainly poor bureaucratic quality.

\section{The Sanding Hypothesis}

This strand argues that corruption directly and negatively affects economic performance (Mauro, 1995; Mo, 2001; Guetat, 2006; Dridi, 2013) by distorting the institutional environment in which the firm operates. We focus here on the arguments related to innovative performance. Beyond the moral considerations, the literature perceives corruption as a hindering factor to innovation due to four main arguments (Anokhin and Schultze, 2009).

First, the decision to undertake an innovative project or business opportunity is heavily influenced by the share of the profit that can be appropriated by the firm (Amit and Schoemaker, 1993). When corruption is present, the firm faces an increased risk and uncertainty that others may appropriate part of the rents to which the firm beliefs it is entitled, reducing the incentive to innovate.

Second, more generally, any resources allocated to corruption could have been invested in $R \& D$, especially in the firms' early-stage phase. Corruption thus increases transaction costs through bribery payments and efforts to build connections with bureaucrats. This limits the scope of investment in productive activities and reduces the subset of innovative projects that 
can be commercially exploited. Higher levels of corruption raise transaction costs and can make 'promising innovative opportunities difficult to commercialize profitably' (Anokhin and Schulze, 2009).

Third, there is an effect of corruption on the allocation of entrepreneurial talents. Countries' incentive structure will largely determine whether the better entrepreneurial talents are attracted to productive activities such as innovation or on the contrary to unproductive or destructive activities such as rent seeking and crime (Baumol, 1990). In countries where corruption is high, the more talented people will be attracted towards more rewarding rentseeking activities, develop specialized skills in this area, depressing human capital formation for innovation and growth (Murphy et al, 1993).

Finally, it also affects other important institutions needed to spur innovation. It erodes economic agents' trust in the government and its related institutions and officials undermining innovative investments. It favors a particular class of people and creates inequality in opportunities. This may frustrate those who do not benefit from privileges in the system and lead to social unrest and instability (Mo, 2001).

\section{The "Greasing" effect of corruption}

However, some researchers suggest that corruption may positively impact on growth and innovation (Leff, 1964; Huntington, 1968, Acemoglu and Verdier, 1998). Bribery payment may lead to more efficient systems in the allocation of business licensing and government contracts as only the more efficient firms are able to pay the highest bribes (Beck and Maher, 1986, Lien, 1986). And it may reduce market uncertainty for firms by providing them informational advantages and lobbying power, providing incentives for investment in innovative activity.

The most often heard arguments, based on work by Leff (1964) and Lui (1985), is that corruption is perceived as a factor to overcome other bureaucratic obstacles, even though morally undesirable. Bureaucracy and red tape are major barriers to innovation (Damanpor, 1996), especially in countries with centralized governments (Qian and Xu, 1998). Innovators need to obtain special documents and permits in a short period of time in order to secure a market advantage in the innovation race (Duncan, 1976; Mahagaonkar, 2008). Most of the studies hypothesizing a positive "greasing" effect of corruption on innovation are based on the idea that corruption can counterbalance this negative effect of bureaucratic delay on 
innovation. Therefore, some firms will be motivated to pay some additional "informal payments" or "speed money" to reduce the time lag involved in many bureaucratic procedures (see Fisman and Svensson, 2007).

\section{Evidence from previous studies}

The links between corruption and economic performance have been well studied on the macro level. Mo (2001), Dridi (2013) and Guetat (2006) provide quantitative estimates on the role of corruption in economic growth, be it by raising political instability, hampering human capital accumulation and private investment (Mo, 2001, Dridi, 2013, Guetat, 2006) or by decreasing trust in the ability of the state and market institution to enforce law and trade rules (Anokhin and Schulze, 2009).

These channels also undermine the innovative performance of firms underlying economic growth, as innovation fully requires human capital and skills formation, investment in risky projects and appropriate institutions including trust and property rights protection (Altenburg, 2008; DiRienzo and Das, 2014; Fagerberg and Srholec, 2008).

Meon and Weill (2010) test the greasing hypothesis using macro data, and analyse the interaction between aggregate efficiency, corruption and other dimensions of governance. They find that corruption is less detrimental in countries where institutions are less ineffective and even positive in countries where institutions are extremely ineffective, providing support for the greasing hypothesis.

Based on a meta-analysis study conducted by Ugur and Dasgupta (2011) on 72 empirical studies, there is a stronger direct negative effect in studies with mixed countries than in studies focusing on developing countries only. This is interpreted as supportive for the greasing hypothesis of corruption on growth. Indeed, in developing countries the institutional quality is lower, and therefore there is more reason to engage in bribery and informal payments to speed up bureaucratic procedures, resulting in a less negative effect of corruption on growth.

Evidence on the greasing effect is less abundant at the micro level. The majority of microeconomic studies test the effect of corruption on performance, but they do not focus on the interaction with the severity of other bureaucratic obstacles to test the greasing hypothesis explicitly. 
Fisman and Svensson (2007) find that an increase of one percentage point of the bribery rate decreases firm growth by three percentage points. They used as an industry-location bribery average in order to control for potential problems of endogeneity and measurement errors. Mahagaonkar (2008) tests the greasing vs. sanding hypotheses on four different types of innovation on 3477 firms from 7 Sub-Saharan African countries. Using IV probit estimates, his results support the hypothesis that corruption is a hindrance to product and organizational innovation, while it facilitates marketing innovation and doesn't affect process innovation. He uses the bribery amount over annual sales as the main variable to capture corruption. Similarly, using a probit estimation on around 2000 Indian firms, Waldemar (2012) finds that bribery lowers the level of product innovation, providing evidence for a sanding hypothesis.

Zhou and Peng (2012) provide firm-level evidence from a cross-sectional dataset of 2686 firms in 48 countries. They find that large firms are more likely to engage in strategic bribery, while bribery hurts the growth of small firms.

Using a comparable dataset from Europe and Central and Western Asia and applying a recursive model, Habiyaremye and Raymond (2013) found that there is a positive direct effect of corruption ${ }^{6}$ on innovation for foreign firms only. The authors argue that there is a long-term loss at the national level due to the practices of foreign companies and the resulting disincentive of domestic firms to invest in $R \& D$ and product upgrading.

De Rosa, Gooroochurn and Gorg (2010) use the EBRD and World Bank Business Environment and Enterprise Performance Survey (BEEPS) data, covering Central and Eastern Europe and the Former Soviet Union. They find that corruption ${ }^{7}$ has a negative effect on firm productivity, while lengthy bureaucratic procedures do not affect the productivity directly. The interaction between corruption and bureaucracy has no effects on productivity.

\section{Hypotheses}

We argue that depending on the severity of institutional and bureaucratic obstacles, the effect of corruption on performance may vary. In line with institutional economics, we contend that better quality of institutions and lower levels of corruption are beneficial to innovation and growth, in line with the "sanding effect of corruption" hypothesis. However, in particular

\footnotetext{
${ }^{6}$ Proxied by the bribes from foreign-owned companies to government officials in host countries.

${ }^{7}$ De Rosa et al (2010) define corruption as the occurrence of informal payment request from governmental officials to perform an official task.
} 
circumstances, when red tape is experienced as very severe and hampering the operations of the companies, informal payments may speed up bureaucratic procedures and counterbalance the depressing effect bureaucratic procedures have on firm performance.

Therefore, we believe that the "net impact" of corruption on innovation should be tested by disentangling the direct and interaction effects with other business obstacles. This interaction will be tested throughout the paper, focusing on one aspect of business obstacles, namely bureaucratic procedures.

In the next section we will study these effects, first on firm innovation, measured in different ways, and next we will test the effect of innovation, corruption and institutional obstacles on firm growth.

\section{Empirical Strategy}

\subsection{Data source}

To study the direct and indirect effects of corruption on innovation and firm growth, firmlevel data are used from the World Bank Enterprise Survey consisting of 3,489 firms from Egypt $(2,897)$ and Tunisia (592). This data set is unique as firm-level data in the MENA region, especially on innovation, are quite rare (Atiyas, 2011). Additionally, given the secretive and sensitive feature of corruption, firm-level surveys typically lack quantitative micro data on corruption.

The surveys were conducted in 2013 and 2014 under the Enterprise Survey global methodology, which ensures that all global variables, sampling, and coverage are standardized and fully harmonized across countries (see World Enterprise Survey (2009) for details on the population and sampling methodology). This wave of the Enterprise Survey includes the innovation module, which builds on OECD's Oslo Manual (2005) guidelines for innovation data collection. It distinguishes four types of innovation: whether a firm has introduced a new or significantly improved product, production process, marketing strategy or organizational method.

Due to missing values for key variables the sample size is reduced to a total of 1889 firms for the main estimation. 


\subsection{Empirical model}

Following the discussion in section 2, our main interest focuses on the effect of corruption on innovation and firm growth, and its interaction with other institutional and bureaucratic obstacles, to test a sanding versus greasing effect of corruption. To explain the likelihood that a firm is an innovator, our model includes the focal variables corruption (CORRUPT) and bureaucratic obstacles (BUR). We introduce an interaction of CORRUPT and BUR to study the potential "greasing effect" of corruption at higher levels of bureaucratic obstacles. In addition, a vector of appropriate firm characteristics $X_{i}$ is added. Based on the many findings discussed in the innovation literature (see Wlademar (2012), Bogliacino, Perani, Pianta and Supino (2010) and Mairesse and Mohnen (2007)), the traditional determinants of innovation include a set of dummy variables to capture website ownership ( $W E B$ ), research and development activities $(R D)$, foreign ownership $(F O R)$, foreign-licensed technology (FORTECH), formal employee training (TRAIN) and the educational attainment of the top manager $(U N I V) . \mathrm{R} \& \mathrm{D}$ is the major input in the production function of knowledge. In developing countries, knowledge accumulation often occurs via the acquisition of outside knowledge, e.g. through licensed technologies. Employee training and the educational level of the top manager capture the human capital that facilitates innovation. Foreign-owned firms are generally closer to the technology frontier and better able to innovate. The model also takes into account the main characteristics of the firms including firm size, age, and control dummies for the geographical location in the major cities of Egypt and Tunisia and for the sector of activity.

Next, we are interested in the effect of corruption and innovation on firm growth. It is important to understand the direct effects of corruption on growth as well as its indirect effect through innovation (Dridi, 2013). We therefore estimate a firm employment growth equation, explaining growth by innovation and corruption, while controlling for a slightly different set of relevant firm characteristics directly related to growth, such as firm size at the beginning of the period over which growth is measured and firm age.

In order to control for any possible endogeneity of corruption in the innovation and growth equation we extend our model by adding an equation explaining corruption using, in addition to the other exogenous variables, an exclusion restriction that affects innovation only through corruption (more on this in section 3.3).

The model can be described as follows: 


$$
\left\{\begin{array}{c}
\text { CORRUPT }_{i}=1\left[\alpha_{X} X_{1 i}+\alpha_{Z} Z_{1 i}+\varepsilon_{1 i}>0\right] \\
\text { INNOV }_{i}=1\left[\gamma_{X} X_{2 i}+\gamma Z_{2 i}+\gamma_{B} B U R_{i}+\varepsilon_{2 i}>0\right] \\
\text { GROWTH }_{i}=\beta_{X} X_{3 i}+\beta_{c} \text { CORRUP }_{i}+\beta_{I} I_{N N O V_{i}}+\varepsilon_{3 i}
\end{array}\right.
$$

The first equation explains the likelihood that a firm engages in corruption, the second explains the probability that a firm is an innovator and the third equation is an employment growth equation. The first two equations correspond to probit models, the last equation is a simple linear regression. $Z_{1}$ and $Z_{2}$ are exclusion restrictions that allow to identify the effects of corruption (CORRUPT) and innovation (INNOV) on employment growth while BUR represents bureaucratic obstacles, and $X_{1}$ to $X_{3}$ are vectors of relevant firm characteristics and other control variables. We assume the three error terms to be jointly normally distributed. Because of the simultaneity, we estimate the three equations by full information maximum likelihood combining continuous and discrete endogenous variables ${ }^{8}$.

\subsection{Key variables}

We measure innovation (INNOV) using any of the four types of innovation - product innovation (PRODUCT), process innovation (PROCESS), organizational (ORG) or marketing innovation (MARK) - with an emphasis on product innovation in the main specification. The innovation outputs are measured as binary variables since continuous data related to innovation ${ }^{9}$ in our dataset are missing for a significant number of observations, and in any case only available for product innovations.

Our main explanatory variable of interest is corruption. CORRUPT measures whether the firm perceives corruption as a factor increasing its annual costs. It is captured by the answer to the question:

"Would this establishment's total annual costs increase, remain the same or decrease over the next fiscal year if corruption is no longer an obstacle?"

The variable takes the value 1 if the firm has answered "decrease" and 0 otherwise.

\footnotetext{
8 The estimation uses the Conditional Mixed Process program developed by Roodman (2011).

${ }^{9}$ A continuous measure of product innovation is the percentage of annual sales accounted for by new or significantly improved products.
} 
BUR is our proxy for bureaucratic obstacles, and it measures the firm's perception of the difficulty of obtaining business licenses. Innovative firms are considered relatively more sensitive to the institutional environment than non-innovative firms (D'Estea, Rentocchinib and Jurado, 2010; Savignac, 2006). Hence both the firm's innovativeness and its perception on hindrances (notably institutional and corruption) are linked. It is indeed imaginable that firms that innovate are more likely to need the necessary licenses and permits for the introduction of their new products. Therefore they are more likely to experience bureaucratic procedures and red tape as more constraining than firms that do not need government services in this respect. Accordingly, innovators might be more inclined to engage in bribing to get things done. Because it is a subjective indicator and we want to control for the tendency of innovative firms to complain more, we normalize it relatively to the scores of eleven other business obstacles ${ }^{10}$ as follows:

$B U R_{i}=$ Permit_Score $_{i} / \frac{\sum_{j=1}^{11} \text { Other_Scores }_{i j}}{11}$.

It thus represents the perceived difficulty of getting permits and licenses relative to the perceived severity of all obstacles.

As exclusion restrictions in the corruption equation, we first choose the AUDIT variable, which is a dummy variable indicating whether the firm had recourse to external auditors to certify and check its annual financial statement. According to Brown, Jappelli and Pagano (2009) and Leiponen and Zhang (2010), being audited indicates a high level of transparency and information sharing with external entities. Firms that get audited externally find themselves on the horns of a dilemma. They are expected, on the one hand, to exert efforts in book-keeping procedures and to share details of their financial transactions with an external auditor in a transparent way so as to be eligible to access public services and, on the other hand, to enter into contractual agreements with governmental entities with a tendency to be forced into corruption (Svensson and Reinikka, 2002). Therefore firms consider corruption as a factor increasing their annual costs but with no direct effects on their decision to innovate.

In the same context, the behavior of a firm is definitely affected by the surrounding "rules of the game" and set of incentives. Tirole (1996) showed that corruption may spread from one segment of the economic agents to the rest of the economy. Thus, when explaining

\footnotetext{
10 The choice of obstacles was based on the availability of a sufficient number of observations. The 11 obstacles to operations are: electricity; transport; access to land; crime, theft and disorder; finance; tax rates; tax administrations; political instability; labor regulations; workforce education and corruption.
} 
corruption of a firm, the behavior of other firms should be taken into account. We therefore construct and use as second exclusion restriction the dummy variable COMP based on whether or not the firm reports one of the following practices by their competitors:

1- $\quad$ Avoid VAT, sales taxes, labour taxes or regulations, duties, trade regulations.

2- $\quad$ Have a favoured access to credit or infrastructure services.

3- $\quad$ Conspire to limit access to markets or supplies.

Table 1 presents the definition of the variables used in the model with their mean value (and standard deviation for the continuous variables).

Table $1 \quad$ Variable description and summary statistics

\begin{tabular}{|c|c|c|c|c|}
\hline \multirow[t]{2}{*}{ Variable } & \multirow[t]{2}{*}{ Description } & \multicolumn{3}{|c|}{ Mean (sd) } \\
\hline & & Total Sample & $\begin{array}{c}\text { Egypt } \\
\text { Only }\end{array}$ & $\begin{array}{c}\text { Tunisia } \\
\text { Only }\end{array}$ \\
\hline CORRUPT & $\begin{array}{l}=1 \text { if a firm perceives corruption as a factor increasing } \\
\text { its costs. }\end{array}$ & 0.45 & 0.39 & 0.68 \\
\hline PRODUCT & $\begin{array}{l}=1 \text { if a firm has introduced new or significantly } \\
\text { improved products or services, excluding the simple } \\
\text { resale of new goods purchased from others and } \\
\text { changes of a solely aesthetic nature. }\end{array}$ & 0.24 & 0.23 & 0.24 \\
\hline PROCESS & $\begin{array}{l}=1 \text { if a firm has introduced new or significantly } \\
\text { improved methods of manufacturing products or } \\
\text { offering services. }\end{array}$ & 0.16 & 0.16 & 0.17 \\
\hline$O R G$ & $\begin{array}{l}=1 \text { if a firm has introduced any new or significantly } \\
\text { improved organizational structures or management } \\
\text { practices during the past three years. } \\
=1 \text { if a firm has introduced new or significantly }\end{array}$ & 0.13 & 0.11 & 0.21 \\
\hline$M A R K$ & $\begin{array}{l}\text { improved marketing methods during the past three } \\
\text { years. }\end{array}$ & 0.20 & 0.18 & 0.27 \\
\hline GROWTH & $\begin{array}{l}\text { Firm growth measured by the difference of logs of the } \\
\text { firm's size at the end of the last fiscal year and three } \\
\text { years earlier. }\end{array}$ & $\begin{array}{l}-0.06 \\
(0.43)\end{array}$ & $\begin{array}{l}-0.09 \\
(0.42)\end{array}$ & $\begin{array}{c}0.03 \\
(0.44)\end{array}$ \\
\hline BUR & $\begin{array}{l}\text { The difficulty of obtaining business licensing and } \\
\text { permits on a scale of } 0 \text { (when it is not considered as an } \\
\text { obstacles) to } 4 \text { (when it is perceived as a very severe } \\
\text { obstacle), measured relatively to } 11 \text { other business } \\
\text { obstacles. }\end{array}$ & $\begin{array}{c}0.62 \\
(0.84)\end{array}$ & $\begin{array}{c}0.69 \\
(0.89)\end{array}$ & $\begin{array}{c}0.33 \\
(0.56)\end{array}$ \\
\hline$A U D I T$ & $\begin{array}{l}=1 \text { if the firm has its annual financial statements } \\
\text { checked and certified by an external auditor in the last } \\
\text { fiscal year }\end{array}$ & 0.78 & 0.78 & 0.77 \\
\hline BRIBE & $\begin{array}{l}\text { The percentage of total annual sales, or estimated total } \\
\text { annual value, paid in "informal payments or gifts" to } \\
\text { public officials for the purpose of getting things done. }\end{array}$ & $\begin{array}{l}0.48 \\
(3.2)\end{array}$ & $\begin{array}{c}0.49 \\
(2.13)\end{array}$ & $\begin{array}{c}0.44 \\
(6.18)\end{array}$ \\
\hline COMP & $\begin{array}{l}=1 \text { if a firm perceives the conduct of surrounding } \\
\text { firms as corrupt }\end{array}$ & 0.62 & 0.55 & 0.85 \\
\hline$S M A L L$ & $=1$ if the firm's size is between 5 and 20 employees & 0.41 & 0.42 & 0.37 \\
\hline
\end{tabular}

11 See Sub-Section 3.2. 


\begin{tabular}{|c|c|c|c|c|}
\hline MEDIUM & $=1$ if the firm's size is between 20 and 100 employees & 0.38 & 0.37 & 0.41 \\
\hline$L A R G E$ & $=1$ if the firm has more than 100 employees & 0.21 & 0.21 & 0.22 \\
\hline LOGEMP & $\begin{array}{l}\text { The log of the firm's size (in number of permanent } \\
\text { full-time employees). }\end{array}$ & $\begin{array}{c}3.52 \\
(1.41)\end{array}$ & $\begin{array}{c}3.51 \\
(1.43)\end{array}$ & $\begin{array}{c}3.56 \\
(1.36)\end{array}$ \\
\hline LOGEMP-3 & $\begin{array}{l}\text { The log of the firm's size (in number of permanent } \\
\text { full-time employees) three years back }\end{array}$ & $\begin{array}{l}3.58 \\
(1.40)\end{array}$ & $\begin{array}{c}3.60 \\
(1.41)\end{array}$ & $\begin{array}{c}3.53 \\
(1.36)\end{array}$ \\
\hline$L O G A G E$ & The log of the firm's age (in years). & $\begin{array}{c}2.90 \\
(0.65)\end{array}$ & $\begin{array}{c}2.89 \\
(0.66)\end{array}$ & $\begin{array}{c}2.95 \\
(0.60)\end{array}$ \\
\hline FOR & $\begin{array}{l}=1 \text { if the foreign ownership of the firm is larger than } \\
20 \text { percent }\end{array}$ & 0.11 & 0.10 & 0.15 \\
\hline FORTECH & $\begin{array}{l}=1 \text { if the firm at present uses technology licensed from } \\
\text { a foreign-owned company (excluding office software). }\end{array}$ & 0.08 & 0.08 & 0.06 \\
\hline$R D$ & $\begin{array}{l}=1 \text { if a firm has conducted any Research } \& \\
\text { Development activities }\end{array}$ & 0.10 & 0.08 & 0.18 \\
\hline TRAIN & $\begin{array}{l}=1 \text { if a firm has conducted any formal training } \\
\text { programs for its permanent, full-time employees. }\end{array}$ & 0.18 & 0.13 & 0.35 \\
\hline UNIV & $=1$ if the top manager has at least a university degree. & 0.79 & 0.81 & 0.71 \\
\hline$W E B$ & $=1$ if a firm has its own website. & 0.53 & 0.49 & 0.68 \\
\hline
\end{tabular}

\section{Estimated Results}

In Table 2 we present the results of the CMP model, estimating the impact of CORRUPT and BUR once without their interaction (column 1) and once with an interaction term between them (column 2). The correlation coefficients between the three error terms are significantly different from zero and justify our concerns of the endogeneity of corruption and innovation. In the following sub-sections we discuss the outcomes of each individual equation.

\subsection{Corruption Determinants}

Both sub-columns (1.a) and (2.a) explain the main determinants of corruption and include the instrumental variable to control for endogeneity. There are no significant changes in the results between the two specifications.

Our corruption indicator appears to be significantly correlated with the AUDIT instrumental variable. This provides supportive evidence for the argument that the high level of transparency required to conduct an external audit pushes firms to perceive corruption as a liability and does not necessarily prevent it.

The corruptive conduct of a firm is highly and positively correlated with its perception of the integrity of its competitors (COMP), which is aligned with the theory of collective 
reputations by Tirole (1996). Firms that perceive other competitors as conducting corruptive activity are more likely to engage in corruptive activities themselves.

Other explanatory variables show that the development of a firm's human capital through training has a negative and significant effect on corruption. Neither education nor firm size appears to be correlated with corruption. This contradicts with earlier arguments that small firms are more harmed by corruption due to their weaker lobbying and negotiation powers. 
Table 2 Estimated coefficients of the CMP Model

\begin{tabular}{|c|c|c|c|c|c|c|}
\hline & \multicolumn{3}{|c|}{$\begin{array}{c}\text { (1) } \\
\text { without interaction }\end{array}$} & \multicolumn{3}{|c|}{$\begin{array}{c}\text { (2) } \\
\text { with interaction }\end{array}$} \\
\hline & (1.a) & (1.b) & $(1 . c)$ & (2.a) & $(2 . b)$ & $(2 . c)$ \\
\hline & CORRUPT & PRODUCT & GROWTH & CORRUPT & PRODUCT & GROWTH \\
\hline $\begin{array}{l}\text { Country \& Sectors } \\
\text { Dummies }\end{array}$ & Yes & Yes & Yes & Yes & Yes & Yes \\
\hline AUDIT & $\begin{array}{l}0.248 * * * \\
(0.092)\end{array}$ & & & $\begin{array}{l}0.247 * * * \\
(0.0919)\end{array}$ & & \\
\hline COMP & $\begin{array}{l}0.425 * * * \\
(0.080)\end{array}$ & & & $\begin{array}{l}0.424 * * * \\
(0.079)\end{array}$ & & \\
\hline SMALL & $\begin{array}{l}0.183 \\
(0.174)\end{array}$ & $\begin{array}{l}-0.332 * * \\
(0.143)\end{array}$ & & $\begin{array}{l}0.183 \\
(0.173)\end{array}$ & $\begin{array}{l}-0.322 * * \\
(0.140)\end{array}$ & \\
\hline MEDIUM & $\begin{array}{l}-0.023 \\
(0.130)\end{array}$ & $\begin{array}{l}-0.173^{*} \\
(0.099)\end{array}$ & & $\begin{array}{l}-0.023 \\
(0.130)\end{array}$ & $\begin{array}{l}-0.169 * \\
(0.090)\end{array}$ & \\
\hline LOGAGE & $\begin{array}{l}0.057 * \\
(0.034)\end{array}$ & $\begin{array}{l}-0.019 \\
(0.041)\end{array}$ & $\begin{array}{l}-0.171 * * * \\
(0.042)\end{array}$ & $\begin{array}{l}0.057 * \\
(0.034)\end{array}$ & $\begin{array}{l}-0.020 \\
(0.041)\end{array}$ & $\begin{array}{l}-0.172 * * * \\
(0.043)\end{array}$ \\
\hline WEB & $\begin{array}{l}0.255^{* * *} \\
(0.065)\end{array}$ & $\begin{array}{l}0.153^{*} \\
(0.079)\end{array}$ & $\begin{array}{l}0.096 * * * \\
(0.030)\end{array}$ & $\begin{array}{l}0.255 * * * \\
(0.065)\end{array}$ & $\begin{array}{l}0.166^{* * *} \\
(0.079)\end{array}$ & $\begin{array}{l}0.097 * * * \\
(0.030)\end{array}$ \\
\hline TRAIN & $\begin{array}{l}-0.324 * * * \\
(0.099)\end{array}$ & $\begin{array}{l}0.477 * * * \\
(0.091)\end{array}$ & $\begin{array}{l}0.027 \\
(0.035)\end{array}$ & $\begin{array}{l}-0.323 * * * \\
(0.099)\end{array}$ & $\begin{array}{l}0.466 * * * \\
(0.091)\end{array}$ & $\begin{array}{l}0.031 \\
(0.034)\end{array}$ \\
\hline UNIV & $\begin{array}{l}0.099 \\
(0.076)\end{array}$ & $\begin{array}{l}-0.008 \\
(0.085)\end{array}$ & $\begin{array}{l}0.049 * \\
(0.029)\end{array}$ & $\begin{array}{l}0.099 \\
(0.076)\end{array}$ & $\begin{array}{l}-0.003 \\
(0.086)\end{array}$ & $\begin{array}{l}0.049 * \\
(0.029)\end{array}$ \\
\hline $\mathrm{RD}$ & & $\begin{array}{l}0.998 * * * \\
(0.104)\end{array}$ & & & $\begin{array}{l}1.009 * * * \\
(0.103)\end{array}$ & \\
\hline FOR & & $\begin{array}{l}0.191 * * \\
(0.097)\end{array}$ & & & $\begin{array}{l}0.182^{*} \\
(0.097)\end{array}$ & \\
\hline FORTECH & & $\begin{array}{l}0.362 * * * \\
(0.108)\end{array}$ & & & $\begin{array}{l}0.349 * * * \\
(0.109)\end{array}$ & \\
\hline BUR & & $\begin{array}{l}-0.0211 \\
(0.038)\end{array}$ & & & $\begin{array}{l}-0.137 * * \\
(0.056)\end{array}$ & \\
\hline CORRUPT & & $\begin{array}{l}0.303 \\
(0.190)\end{array}$ & $\begin{array}{l}-0.341^{* *} \\
(0.158)\end{array}$ & & $\begin{array}{l}0.107 \\
(0.199)\end{array}$ & $\begin{array}{l}-0.341 * * \\
(0.157)\end{array}$ \\
\hline BUR*CORRUPT & & & & & $\begin{array}{l}0.273 * * * \\
(0.082)\end{array}$ & \\
\hline LOGEMP-3 & & & $\begin{array}{l}-0.141 * * * \\
(0.0337)\end{array}$ & & & $\begin{array}{l}-0.141 * * * \\
(0.034)\end{array}$ \\
\hline $\begin{array}{l}\text { LOGAGE* } \\
\text { LOGEMP-3 }\end{array}$ & & & $0.0258 * *$ & & & $0.026 * *$ \\
\hline PRODUCT & & & $\begin{array}{l}(0.0107) \\
0.246 * * * \\
(0.0737)\end{array}$ & & & $\begin{array}{l}(0.011) \\
0.229 * * * \\
(0.070)\end{array}$ \\
\hline _cons & $\begin{array}{l}0.136 \\
(0.307)\end{array}$ & $\begin{array}{l}-0.814 * * \\
(0.333)\end{array}$ & $\begin{array}{l}0.802 * * * \\
(0.195)\end{array}$ & $\begin{array}{l}0.135 \\
(0.307)\end{array}$ & $\begin{array}{l}-0.723 * * \\
(0.333)\end{array}$ & $\begin{array}{l}0.808 * * * \\
(0.194)\end{array}$ \\
\hline rho_12 & $\begin{array}{l}-.240 * * \\
(0.117)\end{array}$ & & & $\begin{array}{l}-0.230 * * \\
(0.116)\end{array}$ & & \\
\hline rho_13 & $\begin{array}{l}0.565 * * * \\
(0.199)\end{array}$ & & & $\begin{array}{l}0.566 * * * \\
(0.198)\end{array}$ & & \\
\hline rho_23 & $\begin{array}{l}-0.365 * * * \\
(0.112)\end{array}$ & & & $\begin{array}{l}-0.339 * * * \\
(0.108)\end{array}$ & & \\
\hline $\mathrm{N}$ & 1889 & & & 1889 & & \\
\hline
\end{tabular}

Standard errors in parentheses; $* \mathrm{p}<0.10, * * \mathrm{p}<0.05, * * * \mathrm{p}<0.01$ 


\subsection{Corruption and Innovation}

Our main interest is in the effect of corruption and bureaucratic obstacles on innovation activities of the firms. In table 2, we consider only product innovations. Sub-column 1.b shows that there are no direct significant effects of corruption and bureaucracy on innovation. However, as hypothesized on the basis of the literature, we observe a mediating effect of the institutional quality measured by BUR, on the effect of corruption on innovation. In column 2.b, by including an interaction term of corruption and bureaucratic obstacle, the magnitude and significance of our focal explanatory variables change dramatically. The coefficients of bureaucracy become negative and significant, while the coefficient of the interaction term is positive and significant. This means that, while bureaucratic procedures directly decrease the likelihood that a firm is innovative, the coexistence of corruption and bureaucratic obstacles facilitates the introduction of product innovations. This result suggests an indirect "greasing" effect whenever corruption is needed to overcome institutional bureaucratic barriers to innovation.

To interpret the coefficient more meaningfully, we calculated the predicted probabilities of being a product innovator at different levels of BUR and for different values of CORRUPT, as presented in Figure 1. By analyzing the effects of corruption (Williams, 2012) in the model's specification with interaction, we find that the effect of corruption on the probability to innovate increases with the increase of the bureaucratic obstacle. However, when there is no obstacle, the effect is not significant.

For instance, if the firm perceives bureaucracy in getting permits and business licenses twice as severe as the rest of other operational obstacles (i.e. BUR=2), corruption will increase the probability to innovate by $16.6 \%$. 
Figure 1: Predicted probability of product innovation (pr(PROD)), at different levels of bureaucratic obstacles (BUR) and different values of corruption (CORRUPT)

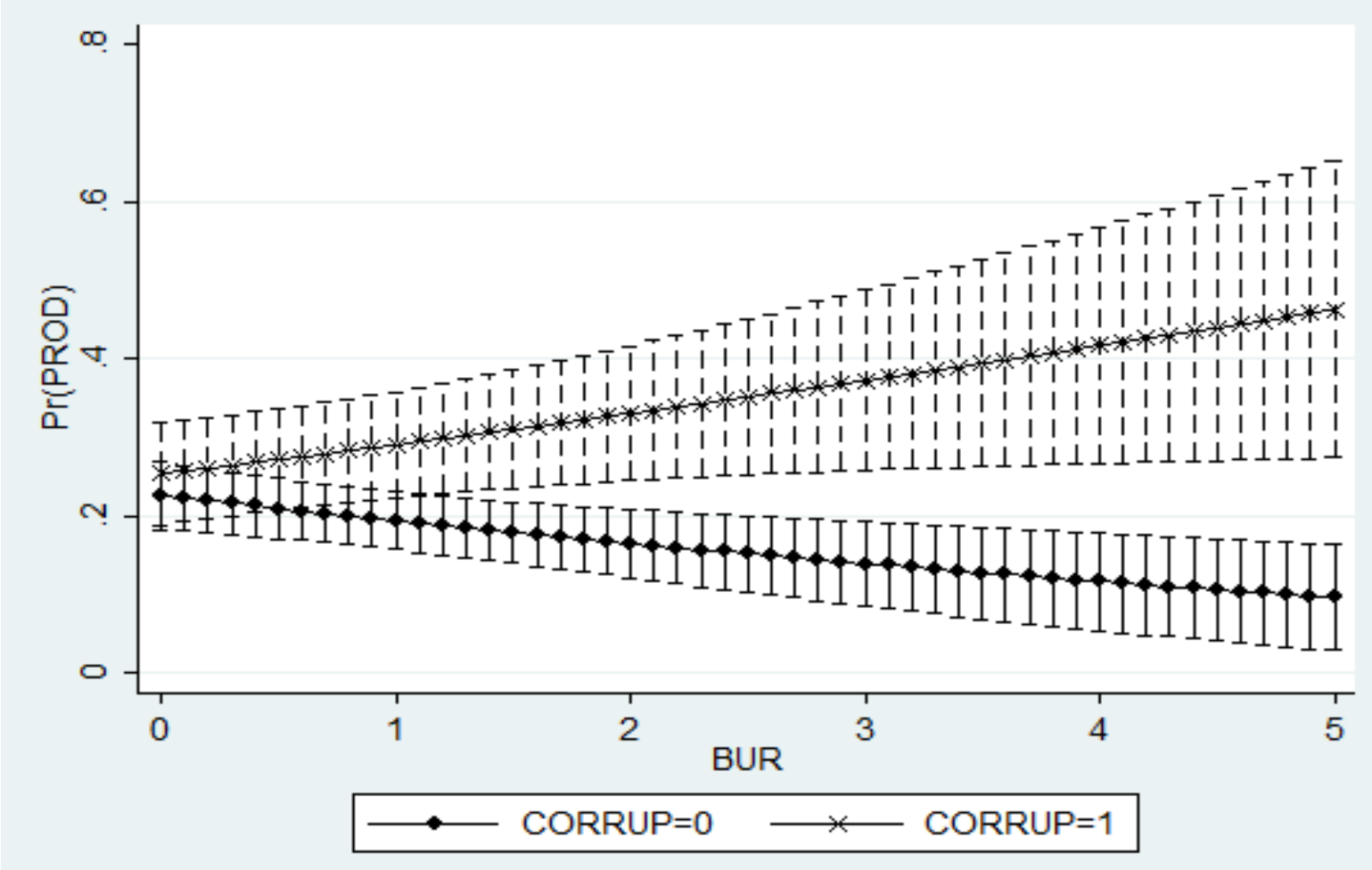

Interestingly, by analyzing such interactions at different values of the bureaucratic obstacles $B U R$, we find that the probability to innovate increases for firms engaged in corruption $($ CORRUPT $=1)$ at higher levels of severity of bureaucratic obstacle, ranging from 25.3 percent probability of innovation when BUR is reported at its minimum level ${ }^{12}$ to 46.3 percent when BUR it is at its maximum level with a confidence level of $95 \%$. In contrast, when CORRUPT equals zero, i.e. if the firm is not engaged in corruption, the probability to innovate will go from 22.6 percent to 9.6 percent as bureaucracy (BUR) takes higher values. It is important, nevertheless, to mention that the net effect of CORRUPT gets statistically insignificant at $95 \%$ level of confidence when the BUR variable is less than 0.9. This means that corruption has no significant impact on innovation for firms that suffer less from bureaucratic obstacles.

This positive interaction term supports our greasing hypothesis. A major amount of time spent on corruptive activities is directed to ease bureaucratic barriers and "get things done"

12 The minimum level of bureaucracy (0) would indicate that the firm has found that the obstacle of getting a business license or permit is the least important relative to the other 11 business obstacles in the dataset. 
for firms to allocate more time and effort on innovative activities. However, if the firm doesn't suffer from major bureaucratic constraints, expenses allocated to corruption have no clear effects on innovation. Notice that the positive marginal effect of corruption on innovation includes the interaction term between corruption and bureaucracy.

By calculating the average marginal effect of other explanatory variables of interest we found that, as expected, foreign technology has a positive and significant impact on product innovation indicating that firms owning foreign technologies are $8.7 \%$ more likely to introduce new products or services. Likewise, if a firm has foreign ownership higher than $20 \%$, it will have a $4.5 \%$ higher probability to introduce a product innovation.

The results show that knowledge accumulation through $\mathrm{R} \& \mathrm{D}$, formal training programs for employees and advanced usage of ICT are positively and significantly correlated with product innovation. This supports the importance of these conventional innovation determinants in developing new products, regardless of the industry and location of operation.

The size of the firm is very significant in explaining innovation. The larger the firms the more likely they are to introduce new products (see column 1 of appendix table 1).

The level of education of the top manager is not correlated with product innovation. This finding is somewhat unexpected, as education is in most studies found to be positively correlated with product innovation, (Habiyaremye and Raymond, 2013; Krastanova, 2014). It shows that product innovation in developing countries of the MENA region is of an incremental type that does not necessarily involve complex processes requiring higher level of knowledge and absorptive capacity.

Also validating our hypothesis, product innovation is less common in the traditional rentier sectors that contribute to a wide portion of the economy of MENA, such as tourism (proxied by Hotels and Restaurants), construction and real estate, refined petroleum products, and plastics, rubber and non-metallic minerals. This finding is derived from the estimated sectoral marginal effects ${ }^{13}$ and the descriptive statistics per sector (see appendix table 2).

The results of the employment growth equation are presented in Table 2, columns 1.c and 2.c. Again, the results do not differ much between the two specifications.

Results from the third equation also show that, as expected, innovation has a positive and significant effect on growth. This is in line with other studies that find that innovation is a

\footnotetext{
13 Results are available upon request.
} 
major determinant for the growth and high growth of firms (Goedhuys and Sleuwaegen, 2010, Coad and Rao, 2008).

The results show that corruption seems to have a direct negative effect on growth, as indicated by the negative and significant coefficient of the corruption variable. This is in line with the findings of Ugur and Dasgupta (2011). However, from the previous discussion we also observe a positive indirect effect of corruption on employment growth through its impact on innovation. Appendix table 1, part B, column 1 reports the marginal effects of the explanatory variables on employment growth. Results show that the positive indirect impact of corruption on employment growth $(0.07 * 0.09)$ is outweighed by the direct negative one (0.137). The occurrence of corruption is estimated in total to decrease the growth of employment by $13 \%$.

The other covariates have the expected sign and significance. Smaller and younger firms grow faster, but the relationship is non-linear. Firms connected through a website, and firms managed by higher educated managers also exhibit higher growth rates by 3.3 and 2.1 percentage points respectively.

We have also estimated our model on the other 3 types of innovation, namely process innovation, marketing and organizational innovation. The results are also presented in Appendix Table 1, in Part A column (2) to (4) for innovation and Part B column (2) to (4) for employment growth; marginal effects are shown. We found that the indirect greasing effect through innovation exists for all types of innovation and that the direct sanding effect varies between $11.7 \%$ for organizational innovation and $13.3 \%$ for product innovation. The result indicates that the sanding effect is more apparent in the type of innovation in which other stakeholders and government officials are typically more involved. This is indeed an interesting argument to be tested more deeply in the future.

In order to test the robustness of our results, we still applied another corruption variable using the BRIBE variable (as defined in table 1). This estimation showed that an increase of one percentage point of the bribery level over annual sales, when bureaucratic obstacles are twice as severe as other obstacles (at $\mathrm{BUR}=2$ ), raises the probability to innovate by $0.4 \%$. Again we found a greasing effect of bribery on innovation and a sanding effect in total on employment growth. 


\section{Conclusion and Policy Implications}

The question of corruption has received a lot of attention in both the political debate and macro-economic studies recently. However, the effect of corruption on innovation in firms is after all not widely explored in the micro-economic literature. This paper provides some novel insights about the effects of corruption on innovation and employment growth in the MENA region, using evidence from Egypt and Tunisia.

In addition to serious ethical considerations, it can be argued that corruption directly hinders innovation by reducing the overall trust in the market and the national innovation system and by channelling investments away from productive projects. Both effects depress the likelihood that firms innovate. However, we have shown that an interaction may exist between corruption and other institutional obstacles. Potentially innovative firms may be tempted to use corruptive practices to overcome the institutional obstacles to innovation they face. Our study finds supportive evidence that corruption indeed interacts with and reduces the negative effect bureaucratic red tape has on innovation. In sound business environments, corruption -as a pragmatic tool to overcome bureaucratic obstacles- loses its importance and appears to have a negative or no effect on product innovation. The findings of our study validate studies in the macroeconomic literature where corruption is less negatively correlated with growth in countries with weak governance efficiency. Despite this greasing effect of corruption in innovation, the sanding effect dominates when it comes to employment growth.

The policy implications of these findings are evident. In the first place, corruption should be fought for ethical reasons, as the system is based on abuse of power and seriously affects the overall trust in the government, leading to social unrest, disinvestment and leaks in the national welfare. Second, innovation should be triggered by sound innovation policies. In many MENA countries only few rigorous innovation policies have been put in place (World Bank, 2013). Therefore, policy makers are highly advised to undertake serious measures to spur innovative activities within firms, for instance by eliminating the different institutional barriers which open the door for rent-seeking behaviour and are hindering innovation, growth and job creation. Inducing more innovation-friendly and transparent business licensing procedures can be done by enforcing, for instance, e-government services, which are 
designed to accelerate the time spent in processing governmental services, eliminating unnecessary intermediaries and inducing a fair access to information and services. Such policies should also focus on peripheral areas which have high potential for innovation and not be privileged to firms based in capital cities only.

Despite the sound results, the analysis has some limitations. We have tackled the simultaneity of corruption and innovation by adding to our model a structural equation explaining corruption. Because of the cross-sectional nature of our data we cannot examine dynamics and run a Granger causality test to find out whether it is corruption that influences innovation or whether it are innovative enterprises that tend to be corrupt. Another important limitation of our research is that the data set that we used for the analysis does not include any informal establishments or firms with less than five employees. This is the main shortcoming of the dataset since the level of informality and the presence of microenterprises are abundant in the MENA economies ${ }^{14}$. Accordingly, there is a room for further research in this area.

\section{References}

Acemoglu, D. \& Verdier, T., 1998. Property rights, corruption and the allocation of talent: a general equilibrium approach. The Economic Journal, 108, pp.1381-1403.

Altenburg, T., 2008. Building inclusive innovation systems in developing countries - why it is necessary to rethink the policy agenda. In IV Globelics Conference at Mexico City, September 22-24 2008. pp. 1-17.

Amit, R. \& Schoemaker, P.J.H., 1993. Strategic assets and organizational rent. Strategic Management Journal, 14(1), pp.33-46.

Andvig, J.C. \& Fjeldstad, O., 2000. Research on Corruption: A Policy Oriented Survey. Oslo: NORAD.

Anokhin, S. \& Schulze, W.S., 2009. Entrepreneurship, innovation, and corruption. Journal of Business Venturing, 24(5), pp.465-476.

Atiyas, I., 2011. Firm-Level Data in the Mena Region: Research Questions, Data Requirements and Possibilities. Middle East Development Journal, 3(2), pp.159-190.

Baumol, W.J., 1990. Entrepreneurship: Productive, Unproductive, and Destructive. Journal of Political Economy, 98(5), pp.893-921.

Bogliacino, F. et al., 2012. Innovation and Development: The Evidence From Innovation Surveys. Latin American Business Review, 13(3), pp.219-261.

Brown, M., Jappelli, T. \& Pagano, M., 2009. Information sharing and credit: Firm-level evidence from transition countries. Journal of Financial Intermediation, 18(2), pp.151-172.

Coad, A. \& Rao, R., 2008. Innovation and firm growth in high-tech sectors: A quantile regression approach. Research Policy, 37(4), pp.633-648.

\footnotetext{
${ }^{14}$ Estimated at 25\% of the GDP (Jütting \& Laiglesia, 2009).
} 
Cornell University, INSEAD \& WIPO, 2015. Global Innovation Index 2015: Effective Innovation Policies for Development. Fontainebleau, Ithaca, and Geneva.

D'Estea, P., Rentocchinib, F. \& Jurado, J.M.V., 2010. Lowering barriers to engage in innovation: evidence from the Spanish innovation survey. In 8th International Triple Helix Conference. pp. $1-14$

Damanpor, F., 1996. Bureaucracy and innovation revisited: Effects of contingency factors, industrial sectors, and innovation characteristics. The Journal of High Technology Management Research, 7(2), pp.149-173.

De Rosa, D., Gooroochurn, N. \& Gorg, H., 2010. Corruption and productivity: firm-level evidence from the BEEPS survey. Policy Research Working Paper Series no. 5348, Washington D.C.: The World Bank.

DiRienzo, C. \& Das, J., 2015. Innovation and role of corruption and diversity: A cross-country study. International Journal of Cross Cultural Management, 15(1), pp.51-72.

Dridi, M., 2013. Corruption and Economic Growth: The Transmission Channels. Journal of Business Studies Quarterly, 4(4), pp.121-152.

Duncan, R.B., 1976. The ambidextrous organization: Designing dual structures for innovation. In The management of organization design - Strategies and Implementation. New York, NY: NorthHolland Publications, pp. $167-189$.

Edquist, C. \& Jöhnson, B., 1997. Institutions and Organisations in Systems of Innovation. In Systems of Innovation: Technologies, Institutions and Organizations. London: Pinter Publishers/Cassel Academic, pp. 41-60.

Fagerberg, J. \& Srholec, M., 2008. Technology and development: Unpacking the relationship(s). TIK Working Papers on Innovation Studies no. 20080623. Oslo: TIK.

Fisman, R. \& Svensson, J., 2007. Are corruption and taxation really harmful to growth? Firm level evidence. Journal of Development Economics, 83, pp.63-75.

Freeman, C., 1987. Technology, policy, and economic performance: lessons from Japan. London: Printer.

Galia, F. \& Legros, D., 2004. Complementarities between obstacles to innovation: evidence from France. Research Policy, 33(8), pp.1185-1199.

Goedhuys, M. \& Sleuwaegen, L., 2000. Entrepreneurship and Growth of Entrepreneurial Firms in Cote d'Ivoire. Journal of Development Studies, 36(3), p.123.

Grossman, G.M. \& Helpman, E., 1993. Innovation and Growth in the Global Economy. Cambridge, MA: The MIT Press.

Guetat, I., 2006. The effects of corruption on growth performance of the MENA countries. Journal of Economics and Finance, 30(2), pp.208-221.

Habiyaremye, A. \& Raymond, W., 2013. Transnational corruption and innovation in transition economies. UNU-MERIT Working Paper Series no. 2013-050, Maastricht.

Huntington, S.P., 1968. Political Order and Political Decay. In Political Order in Changing Societies. New Haven: Yale University Press, pp. 1-92.

Jütting, J. \& Laiglesia, J.R., 2009. Is informal normal?: towards more and better jobs in developing countries. Development Center Studies, Paris: OECD Publishing.

Krastanova, P., 2014. Greasing the Wheels of Innovation: How Corruption and Informal Practices of Firms Impact the Level of Innovation in Bulgaria? Central European University.

Lambsdorff, J., 2007. The institutional economics of corruption and reform. Cambridge: Cambridge University Press.

Leff, N.H., 1964. Economic Development Through Bureaucratic Corruption. American Behavioral Scientist, 8, pp.8-14.

Leiponen, A. \& Zhang, J., 2010. Capital Structure and Innovation in Asian Emerging Economies. In Druid Summer Conference "Opening Up Innovation: Strategy, Organization and Technology." pp. $1-49$.

Lui, F.T., 1985. An Equilibrium Queuing Model of Bribery. Journal of Political Economy, 93(4), pp.760-81. 
Lundvall, B.-Å., Joseph, K.J. \& Chaminade, C., 2009. Handbook of Innovation Systems and Developing Countries: Building Domestic Capabilities in a Global Setting, Edward Elgar Publishing.

Mahagaonkar, P., 2008. Corruption and Innovation: A Grease or Sand Relationship? Jena Economic Research Papers no. 2008-17. Jena.

Mairesse, J. \& Mohnen, P., 2007. A survey of innovation surveys: Taking stock of a growing literature. Banque de France Conference on Innovation, pp.1-16.

Mauro, P., 1995. Corruption and Growth. The Quarterly Journal of Economics, 110(3), pp.681-712.

Meon, P.G. \& Weill, L., 2010. Is Corruption an Efficient Grease? World Development, 38, pp.244259.

Mo, P.H., 2001. Corruption and Economic Growth. Journal of Comparative Economics, 29(1), pp.6679.

Mohnen, P. \& Rosa, J., 2001. Les obstacles à l'innovation dans les industries de services au Canada. L'Actualité Economique, 77(2), pp.231-254.

Murphy, K., Shleifer, A. \& Vishny, R., 1993. Why is rent-seeking so costly to growth? The American Economic Review. 83(2), 409-414.

North, D.C., 1990. Institutions, Institutional Change and Economic Performance. Cambridge: Cambridge University Press.

OECD, 1999. Boosting Innovation. Paris: OECD Publishing.

OECD, 2005. Oslo manual: Guidelines for collecting and interpreting innovation data. Third edit, Paris: OECD, p.162.

Qian, Y. \& Xu, C., 1998. Innovation and Bureaucracy Under Soft and Hard Budget Constraints. Review of Economic Studies, 65(1), pp.151-164.

Rodriguez, P. et al., 2006. Three lenses on the multinational enterprise: politics, corruption, and corporate social responsibility. Journal of International Business Studies, 37, pp.733-746.

Romer, P.M., 1990. Endogenous Technological Change. Journal of Political Economy, 98, p.S71.

Roodman, D., 2011. Estimating fully observed recursive Mixed-process models with Cmp. Stata Journal, 11(2), pp.159-206.

Savignac, F., 2006. The Impact of Financial Constraints on Innovation: Evidence from French Manufacturing Firms, Cahiers de la Maison des Sciences Economiques 2006.42.

Svensson, J. \& Reinikka, R., 2002. Measuring and understanding corruption at the micro level. In Corrupt Exchanges: Empirical Themes in the Politics and Political Economy of Corruption, Frankfurt: Nomos Verlag, pp 134-146.

Tirole, J., 1996. A Theory of Collective Reputations (with Applications to the Persistence of Corruption and to Firm Quality). The Review of Economic Studies, 63(1), pp.1-22.

Transparency International, 2015. Corruption Perception Index 2015. Available at: http://www.transparency.org/cpi2015/.

Ugur, M. \& Dasgupta, N., 2011. Corruption and economic growth: A meta-analysis of the evidence on low-income countries and beyond, MPRA working paper no. 31226.

Waldemar, F.S., 2012. New Products and Corruption: Evidence from Indian Firms. The Developing Economies, 50(3), pp.268-284.

Williams, R., 2012. Using the margins command to estimate and interpret adjusted predictions and marginal effects. Stata Journal, 12, pp.308-331.

World Bank, 2013. Transforming Arab Economies: Traveling the Knowledge and Innovation Road, Washington D.C.: The World Bank Group.

World Enterprse Survey, 2009. Sampling Methodology. , p.10. Available at: https://www.enterprisesurveys.org/ /media/GIAWB/EnterpriseSurveys/Documents/Methodolog y/Sampling_Note.pdf.

Wziatek-kubiak, A. \& Peczkowski, M., 2010. Complementarities between barriers to innovation: data evidence from Poland, MICRO-DYN Working Paper no. 42/10.

Zhou, J.Q. \& Peng, M.W., 2012. Does Bribery Help or Hurt Firm Growth around the World? Asia

Pacific Journal of Management, 29(4), pp.907-921. 


\section{Appendix}

Table 1: Marginal effects of covariates on innovation and firm growth

\begin{tabular}{|c|c|c|c|c|}
\hline \multicolumn{5}{|c|}{ Part A: Average Marginal Effects on Innovation } \\
\hline INNOV: & Product & Process & Marketing & Organizational \\
\hline \multirow[t]{2}{*}{$\mathrm{RD}$} & $0.250 * * *$ & $0.203 * * *$ & $0.230 * * *$ & $0.145 * * *$ \\
\hline & $(0.024)$ & $(0.018)$ & $(0.023)$ & $(0.018)$ \\
\hline \multirow[t]{2}{*}{ UNIV } & -0.0001 & -0.006 & 0.020 & 0.016 \\
\hline & $(0.021)$ & $(0.019)$ & $(0.022)$ & $(0.019)$ \\
\hline \multirow[t]{2}{*}{ SMALL } & $-0.079 * *$ & -0.033 & -0.060 & $-0.125 * * *$ \\
\hline & $(0.035)$ & $(0.029)$ & $(0.038)$ & $(0.025)$ \\
\hline \multirow[t]{2}{*}{ MEDIUM } & $-0.044^{*}$ & -0.006 & -0.018 & $-0.060 * * *$ \\
\hline & $(0.0247)$ & $(0.021)$ & $(0.025)$ & $(0.018)$ \\
\hline \multirow[t]{2}{*}{ LOGAGE } & -0.006 & -0.006 & -0.013 & -0.014 \\
\hline & $(0.010)$ & $(0.009)$ & $(0.010)$ & $(0.009)$ \\
\hline \multirow[t]{2}{*}{ FOR } & $0.046^{*}$ & $0.055^{* * *}$ & 0.016 & -0.005 \\
\hline & $(0.024)$ & $(0.021)$ & $(0.024)$ & $(0.020)$ \\
\hline \multirow[t]{2}{*}{ WEB } & $0.044 * *$ & $0.029 *$ & $0.043 * *$ & $0.049 * * *$ \\
\hline & $(0.019)$ & $(0.017)$ & $(0.019)$ & $(0.016)$ \\
\hline \multirow[t]{2}{*}{ TRAIN } & $0.115^{* * *}$ & $0.076^{* * *}$ & $0.130 * * *$ & $0.075 * * *$ \\
\hline & $(0.022)$ & $(0.020)$ & $(0.021)$ & $(0.018)$ \\
\hline \multirow[t]{2}{*}{ FORTECH } & $0.086^{* * *}$ & $0.089 * * *$ & $0.059 * *$ & $0.061 * * *$ \\
\hline & $(0.027)$ & $(0.022)$ & $(0.026)$ & $(0.020)$ \\
\hline \multirow[t]{2}{*}{ BUR } & -0.001 & 0.0077 & 0.0003 & 0.007 \\
\hline & $(0.010)$ & $(0.009)$ & $(0.010)$ & $(0.008)$ \\
\hline \multirow[t]{2}{*}{ CORRUPT } & 0.0703 & $0.076^{*}$ & $0.103^{*}$ & $0.096 * *$ \\
\hline & $(0.049)$ & $(0.041)$ & $(0.056)$ & $(0.045)$ \\
\hline \multicolumn{5}{|c|}{ Part B: Average Marginal Effects on Growth } \\
\hline \multirow[t]{2}{*}{ UNIV } & $0.021 * *$ & $0.022 * *$ & $0.018 *$ & $0.019 *$ \\
\hline & $(0.010)$ & $(0.010)$ & $(0.010)$ & $(0.010)$ \\
\hline \multirow[t]{2}{*}{ LOGAGE } & $-0.027 * * *$ & $-0.026 * * *$ & $-0.026 * * *$ & $-0.028 * * *$ \\
\hline & $(0.003)$ & $(0.003)$ & $(0.003)$ & $(0.003)$ \\
\hline \multirow[t]{2}{*}{ WEB } & $0.033 * * *$ & $0.036 * * *$ & $0.031 * * *$ & $0.030 * * *$ \\
\hline & $(0.010)$ & $(0.010)$ & $(0.011)$ & $(0.010)$ \\
\hline \multirow[t]{2}{*}{ TRAIN } & 0.009 & 0.018 & 0.007 & 0.0057 \\
\hline & $(0.014)$ & $(0.013)$ & $(0.015)$ & $(0.013)$ \\
\hline \multirow[t]{2}{*}{ CORRUPT } & $-0.137 * * *$ & $-0.138 * * *$ & $-0.130 * *$ & $-0.132 * *$ \\
\hline & $(0.0503)$ & $(0.047)$ & $(0.059)$ & $(0.053)$ \\
\hline \multirow[t]{2}{*}{ LOGEMP-3 } & $-0.022 * * *$ & $-0.021 * * *$ & $-0.021 * * *$ & $-0.023 * * *$ \\
\hline & $(0.003)$ & $(0.003)$ & $(0.003)$ & $(0.003)$ \\
\hline \multirow[t]{2}{*}{ INNOV } & $0.090 * * *$ & $0.064 * *$ & $0.095 * *$ & $0.133 * * *$ \\
\hline & $(0.028)$ & $(0.027)$ & $(0.037)$ & $(0.022)$ \\
\hline $\mathrm{N}$ & 1889 & 1889 & 1889 & 1889 \\
\hline
\end{tabular}


Table 2: Descriptive statistics of innovation and corruption variables per sector of activity

\begin{tabular}{|c|c|c|c|c|c|}
\hline \multirow{2}{*}{\multicolumn{6}{|c|}{$\begin{array}{l}\text { Sector } \\
\text { Food \& Tobacco }(N=165)\end{array}$}} \\
\hline & & & & & \\
\hline Mean & 0.28 & 0.18 & 0.15 & 0.23 & 0.52 \\
\hline$s d$ & 0.45 & 0.39 & 0.36 & 0.42 & 0.50 \\
\hline \multicolumn{6}{|l|}{ Textiles, Garment \& Leather $(N=361)$} \\
\hline Mean & 0.31 & 0.24 & 0.12 & 0.18 & 0.47 \\
\hline sd & 0.46 & 0.42 & 0.33 & 0.38 & 0.50 \\
\hline \multicolumn{6}{|l|}{ Wood, Paper and Publishing $(N=96)$} \\
\hline Mean & 0.29 & 0.21 & 0.07 & 0.15 & 0.50 \\
\hline sd & 0.46 & 0.41 & 0.26 & 0.35 & 0.50 \\
\hline \multicolumn{6}{|l|}{$\begin{array}{l}\text { Refined } \\
(N=92)\end{array}$ Petroleum Products and Chemical } \\
\hline Mean & 0.24 & 0.14 & 0.13 & 0.21 & 0.45 \\
\hline$s d$ & 0.43 & 0.35 & 0.34 & 0.41 & 0.50 \\
\hline \multicolumn{6}{|l|}{ Plastics, rubber and Non-metallic miner $(N=110)$} \\
\hline Mean & 0.18 & 0.10 & 0.19 & 0.17 & 0.48 \\
\hline$s d$ & 0.39 & 0.30 & 0.39 & 0.38 & 0.50 \\
\hline \multicolumn{6}{|l|}{$\begin{array}{l}\text { Basic metals \& Fabricated metal product } \\
(N=218)\end{array}$} \\
\hline Mean & 0.22 & 0.14 & 0.06 & 0.15 & 0.40 \\
\hline$s d$ & 0.42 & 0.35 & 0.25 & 0.36 & 0.49 \\
\hline \multicolumn{6}{|l|}{$\begin{array}{l}\text { Motor Vehicles, Other Transport Equipment } \\
(N=2)\end{array}$} \\
\hline Mean & 0.50 & 0.00 & 0.00 & 0.00 & 0.00 \\
\hline$s d$ & 0.71 & 0.00 & 0.00 & 0.00 & 0.00 \\
\hline \multicolumn{6}{|l|}{ Furniture and Recycling $(N=61)$} \\
\hline Mean & 0.26 & 0.18 & 0.08 & 0.11 & 0.44 \\
\hline sd & 0.44 & 0.39 & 0.28 & 0.32 & 0.50 \\
\hline \multicolumn{6}{|l|}{ Services of motor vehicles $(N=38)$} \\
\hline Mean & 0.21 & 0.13 & 0.03 & 0.26 & 0.55 \\
\hline sd & 0.41 & 0.34 & 0.16 & 0.45 & 0.50 \\
\hline \multicolumn{6}{|l|}{ Construction $(N=95)$} \\
\hline Mean & 0.22 & 0.14 & 0.18 & 0.27 & 0.33 \\
\hline$s d$ & 0.42 & 0.35 & 0.39 & 0.45 & 0.47 \\
\hline \multicolumn{6}{|l|}{ Wholesale $(N=117)$} \\
\hline Mean & 0.10 & 0.09 & 0.20 & 0.25 & 0.59 \\
\hline$s d$ & 0.30 & 0.29 & 0.40 & 0.43 & 0.49 \\
\hline \multicolumn{6}{|l|}{ Retail $(N=79)$} \\
\hline Mean & 0.14 & 0.09 & 0.10 & 0.18 & 0.52 \\
\hline$s d$ & 0.35 & 0.29 & 0.30 & 0.38 & 0.50 \\
\hline \multicolumn{6}{|l|}{ Hotel and Restaurants $(N=111)$} \\
\hline Mean & 0.17 & 0.12 & 0.14 & 0.21 & 0.45 \\
\hline$s d$ & 0.38 & 0.32 & 0.34 & 0.41 & 0.50 \\
\hline \multicolumn{6}{|l|}{$\begin{array}{l}\text { Transport and Supporting Transport Activities } \\
(N=161)\end{array}$} \\
\hline Mean & 0.12 & 0.06 & 0.11 & 0.14 & 0.32 \\
\hline$s d$ & 0.32 & 0.24 & 0.31 & 0.35 & 0.47 \\
\hline \multicolumn{6}{|l|}{ Post, telecommunication and IT $(N=12)$} \\
\hline Mean & 0.42 & 0.33 & 0.33 & 0.25 & 0.17 \\
\hline$s d$ & 0.51 & 0.49 & 0.49 & 0.45 & 0.39 \\
\hline \multicolumn{6}{|l|}{ Other - non-specified $(N=171)$} \\
\hline Mean & 0.33 & 0.24 & 0.23 & 0.30 & 0.47 \\
\hline$s d$ & 0.47 & 0.43 & 0.42 & 0.46 & 0.50 \\
\hline \multicolumn{6}{|l|}{ Total $(N=1889)$} \\
\hline Mean & 0.24 & 0.16 & 0.13 & 0.20 & 0.45 \\
\hline$s d$ & 0.42 & 0.37 & 0.34 & 0.40 & 0.50 \\
\hline
\end{tabular}

